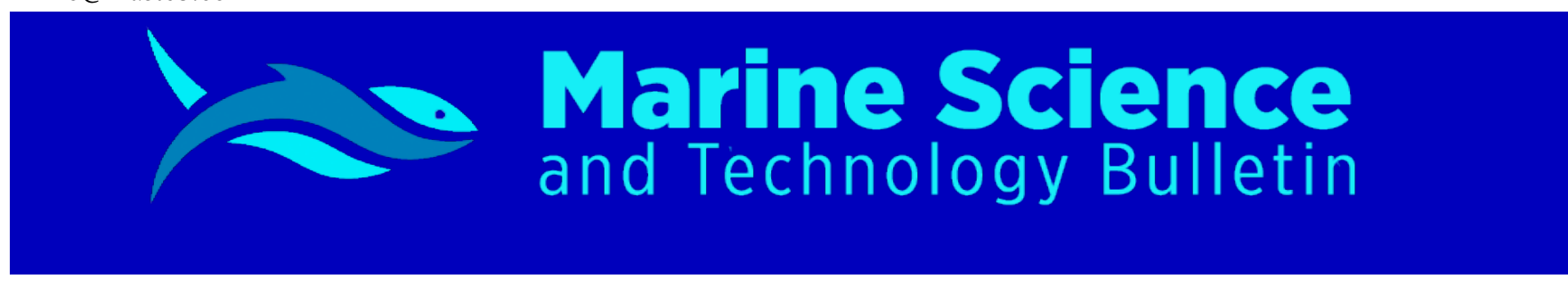

REVIEW PAPER

\title{
Current insights on wastewater treatment and application of Spirulina platensis in improving the water quality
}

\author{
Amruta Padgaonkar ${ }^{1}(\mathbb{D})$ Additiya Paramanya ${ }^{1}$ - Payal Poojari ${ }^{1}$ - Ahmad Ali $^{1 \times}$ \\ ${ }^{1}$ University of Mumbai, Faculty of Science and Technology, Department of Life Sciences, Vidyanagari, Santacruz (East), Mumbai, \\ India
}

\begin{tabular}{l} 
A R T I C L E I N F O \\
\hline Article History: \\
Received: 15.07 .2021 \\
Received in revised form: 10.08 .2021 \\
Accepted: 10.08 .2021 \\
Available online: 06.09 .2021 \\
\hline
\end{tabular}

Keywords:
Bioaccumulation

Bioremediation

Sewage

Spirulina platensis

Wastewater treatment

\begin{abstract}
A B S T RA C T
Excessive generation of wastewater is one of the major reasons for pollution in natural reservoirs. Given the normal circumstances, natural water bodies revive and rejuvenate themselves; but upon increased waste load, the self-revival system of the ecosystem slows down, causing water pollution. Hazardous waste, especially heavy metals and organic pollutants, have affected the ecology to the detriment of humans. Thus, the need arises for wastewater treatment, before its discharge. Current methods undertaken include the use of physical settling of solid waste, filtration, aerobic and anaerobic microbes, and chemical treatments. Low removal of pathogens, dependence on the uninterrupted power supply, high maintenance cost, generation of explosive biogas and bioaccumulation of chemicals are some disadvantages of activated sludge technology, one of the modern technologies used. Hence, the focus has been shifted on organisms capable of metabolizing, immobilizing or absorbing toxic compounds from their environment, making it both environmentfriendly and cost-effective. This review provides perspicacity about the generation of sewage and the various methods available for its treatment. Emphasis is made on bioremediation using Spirulina platensis. Since the organism assimilates the bioavailable contaminants of sewage water photosynthetically; it can overcome the demerits of conventional methods. It also discusses possibilities of using Spirulina grown on the sewage as a food supplement, animal fodder or source of bioactive compounds.
\end{abstract}

Please cite this paper as follows:

Padgaonkar, A., Paramanya, A., Poojari, P., \& Ali, A. (2021). Current insights on wastewater treatment and application of Spirulina platensis in improving the water quality. Marine Science and Technology Bulletin, 10(3), $286-294$. https://doi.org/10.33714/masteb.972128

\section{Introduction}

Anthropogenic pressures on the environment bring about radical transformations in the ecosystem; leading to imbalance and long-term effects. Water pollution causes alterations in water quality and negatively affects the proper use of water. One of the major social and economic concerns is the scarcity of potable water. Thus, it has become a need of the hour to secure this natural resource.

\footnotetext{
* Corresponding author

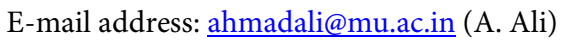


The present domestic wastewater collection, treatment and disposal amenities, in Mumbai, were given in the 1880 s by the governing civic body - Brihanmumbai Municipal Corporation (BMC) - and continued with some development (Gupta et al., 1998). Around 2700 million litres per day (mld) water out of the $3700 \mathrm{mld}$ that is provided by the municipality is tossed into the rivers, lakes, streams or oceans untreated, which accounts for $90 \%$ of total wastewater discharged (UNEP Document Repository, 2002). With the waste overload, the self-revival and self-purification systems are disrupted, leading to problems such as excessive utilisation of dissolved oxygen (DO) (Sperling, 2007).

Developed countries or regions have been dealing with the problem of water pollution by removal of nutrients and micropollutants especially biodegradable organic matter and pathogens, together with attention to stormwater drainage (Amin et al., 2014). Treatment of wastewater is of utmost importance to be able to recirculate the finite resource of water on Earth.

Heavy metal contamination is a global concern as improper discharge poses serious threats to the environment and public health due to persistence, biomagnification and bioaccumulation (Rehman et al., 2007; Wang \& Chen, 2009; Samantaray et al., 2014; Beauvais-Flück et al., 2018). Heavy metals cannot be biodegraded but can be biotransformed (Boopathy, 2000; Juwarkar et al., 2001; Wexler, 2004). Their bioavailability and toxic potential influence the $\mathrm{pH}$, organic matter and nutrient status of water. Consequently, heavy metals may be potentially toxic and hazardous to plants, animals and ultimately humans (Tchounwou et al., 2012).

The focus is on sustainable development for a sustainable environment, due to health-related issues of environmental pollution (Elleuch et al., 2018). Balancing the thin edge between the advancement of technological and economic development, and environmental conservation has been the main focus of sustainability and sustainable development. Human health and examining the long-term outcomes of the actions are aspects that sustainability deals with, apart from just about the environment (WCED, 1987; Boopathy, 2000).

\section{Bioremediation}

Bioremediation or Green Remediation involves the biological deterioration of contaminants into less toxic or nontoxic compounds, using plants, fungi and/or microorganisms (Pierzynski et al., 1994; Abou-Shanab et al., 2011). It is a tactic of taking into account all ecological effects of remedy implementation and incorporating options to ratchet up net environmental benefits of cleanup actions. It aids in mineralizing organic pollutants, partially transforming them or altering their mobility. Bioremediation intensifies the natural rate of degradation of contaminants by facilitating the indigenous microbes, fungi or plants with nutrients, carbon sources, or negatron donors (biostimulation, bio-restoration) or by supplementing enhanced microbial cultures that have distinct characteristics to degrade the required pollutant at a faster rate (bioaugmentation) (Mackay \& Frasar, 2000; Gouma et al., 2014).

Bioremedial agents use organic carbon from the contaminants as an energy source, in turn breaking down the contaminants (Boone \& Castenholz, 2001). Some bioremedial organisms might not mineralize the pollutant instead produce a more potentially toxic compound (Wexler, 2004), but the use of a different organism can work efficiently. Thus, it is important to understand the metabolic and chemical pathways of the said organism, before its use in bioremediation (Juwarkar et al., 2001).

\section{Spirulina platensis}

Spirulina Turpin ex Gomont, 1892 was first isolated by P. J. Turpin from a freshwater lake. Spirulina platensis (Gomont) Geitler 1925 (Figure 1) is a non-branched, helicoidal, filamentous, Gram-negative cyanobacteria (Whitton, 1992; Boone \& Castenholz, 2001; Sánchez et al., 2003). It is identifiable by the organisation of the multicellular barrelshaped trichomes in an open left-hand helix on the entire length. They show a transverse cross wall and seem as a nonheterocystous filament (Paramanya et al., 2019); these filaments are composed of vegetative cells that experience binary fission in a single plane (Vonshak et al., 1996; Habib et al., 2008). Its cell wall comprises a weak envelope, created of multiple layers of peptidoglycan and lipopolysaccharide (Wan et al., 2016). Spirulina is the commercial name for Spirulina platensis, from which a blue pigment - phycocyanin - is extracted (Eriksen, 2008).

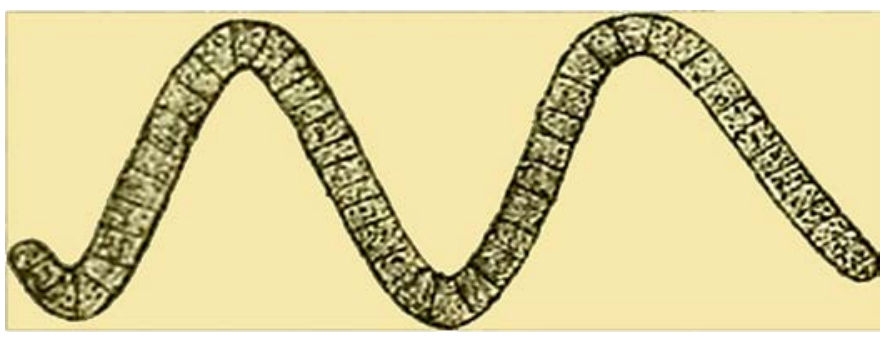

Figure 1. External morphology of Spirulina platensis (Koristka, 1891)

The major photosynthetic pigment in Spirulina sp. is phycocyanin; it conjointly includes chlorophyll a and carotenoids with it. Some may also contain phycoerythrin, a reddish pigment; these pigments facilitate Spirulina sp. to absorb energy from the sun (Habib et al., 2008; Capelli \& 
Cysewski, 2010; Mary Leema et al., 2010). It is an obligate photoautotroph (Barrón et al., 2007); in light conditions, it reduces carbon dioxide and chiefly assimilates nitrates (Richmond, 1986). They also have a mutualistic interaction with nitrogen-fixing bacteria that fix nitrogen from the air (Vo et al., 2008).

It thrives naturally in alkali soda lakes, especially in Africa and Mexico (Ciferri, 2008; Wan et al., 2016). Saline water (>30 $\mathrm{g} / \mathrm{L}$ ) with $\mathrm{pH}$ 8.5-11.0 favours good growth, especially in areas with higher sun's radiation (Vo et al., 2008); Optimum growth is between $35-39^{\circ} \mathrm{C}$ (Richmond, 1986). Extensive Cultivation of Spirulina sp. is straightforward and ensures high biomass for extraction, separation and refinement of high-value bioactive compounds (Barrón et al., 2007). Microalgae like Spirulina sp. are 'biofactories' that have rapid growth and low nutrient necessities (Masojídek \& Torzillo, 2008). Contamination is low as many do not flourish in the high salt environment and generally grow as a unialgal population (Komárek \& Lund, 1998).

Spirulina sp. consists of $55-70 \%$ protein, $15-25 \%$ carbohydrate, $5-6 \%$ total lipids, $6-13 \%$ nucleic acids (DNA and RNA), and 2.2-4.8\% minerals; $25 \%$ branched carbohydrate of the total polysaccharide is structurally comparable to glycogen (Hosseini et al., 2013). It constitutes 1.5-2\% Polyunsaturated Fatty Acids (PUFAs) of the total lipid content (Wan et al., 2016). Different non-saponifiable lipids such as paraffin, terpene alcohol and sterols are present (Falquet, 2008). It is a source of vitamins, viz. B1 (Thiamine), B2 (Riboflavin), B3 (Niacin), B6 (Pyridoxine), B9 (Folate), B12 (Cobalamin) and minerals ( $\mathrm{Cu}, \mathrm{Ca}, \mathrm{Fe}, \mathrm{Cr}, \mathrm{Mn}, \mathrm{Mg}, \mathrm{P}, \mathrm{Se}, \mathrm{Na}$, and $\mathrm{Zn}$ ).

Since the 1500s, it has been a popular food supplement for diets of humans, poultry, livestock and aquaculture - a comprehensive protein source (Wan et al., 2016; Paramanya et al., 2019). Most blue-green algae produce toxins, microcystins, but food supplements of $S$. platensis have so far been cleared for consumption (Koristka, 1891; Chamorro \& Salazar, 1990). If accurately defined free from contaminants and adulterants, it is considered 'Generally Recognized as Safe (GRAS)' by the Food and Drug Administration (Paramanya et al., 2019).

Given all these nutritional qualities of the microalgae, its use in long term use as dietary supplements in Mars missions and other space flights is being scrutinized for (Paramanya et al., 2019). Also, its use in developing countries for malnutrition was suggested by the World Health Organization (WHO) in 2012. The potential applications in combating the food crisis bring forth the necessity for effective and mass production of Spirulina sp. to achieve the requirement.

Phycocyanin is used as a natural colouring agent in food and beverages (Buchweitz, 2016). It has pharmacological activity and a clinically therapeutic effect (Paramanya et al., 2019). Other bioactive compounds in Spirulina sp. are $\gamma$-linoleic acid (Wan et al., 2016; Tanticharoen et al., 2009), sulfated polysaccharides (Hayashi et al., 1996), sulfolipids (Barrón et al., 2007), and insulin-like protein (Anwer et al., 2012). Spirulina sp., other than its popular and extensive application in the food industry and pharmaceuticals, in recent times, is used in genomic studies and also as a model for physiological studies, especially to understand nitrogen assimilation. Spirulina sp. has also found an application in bioremediation.

\section{Spirulina sp. in Bioremediation}

The environment is susceptible to heavy metals because of their persistence and toxicity (Samantaray et al., 2014). Many industries discharge untreated heavy metal waste and pollute soil or water resources. These non-biodegradable pollutants accumulate in the food web (bioaccumulation) and disturb the ecological balance by magnifying up the trophic levels (biomagnification). Conventional water treatment is dominated by physical and chemical strategies, and traditional infrastructure, represented by classical control and treatment plants, viz., evaporation, ion exchange, electroplating, membrane processes or precipitation, to eliminate persistent heavy metals, particularly from liquid waste. They are also high in energy consumption and quite expensive (Priyadarshani et al., 2011).

The enormous potential of biotechnologies in bioremediation is unjustifiably ignored (Cepoia \& Zinicovscaia, 2002). Bioremediation can complete and enhance the efficiency of traditional technologies. Microorganisms have evolved many bioprocesses in the presence of heavy metals, viz. $\mathrm{Pb}, \mathrm{Cu}, \mathrm{Cd}$ and $\mathrm{Zn}$ from wastewater below $50 \mathrm{mg} / \mathrm{L}$, such as transportation across the cytomembrane, biological adsorption to outer cell walls and accumulation in extracellular capsules, precipitation and redox reactions (Chen \& Pan, 2002). Microbes exploit the chemical properties of the metals that are selectively acquired, for catalyzing reactions and also for maintaining protein structure (Murali \& Mehar, 2014).

Due to their ability to survive extreme environments and metabolise a variety of compounds, cyanobacteria are promising in degrading peculiar pollutants and removing heavy metals from wastewater (Kumar et al., 2016). It was found that cyanobacterial growth depends solely on the penetrating light and temperature, whereas nutrients and agitation are not the limitations (Torzilla \& Vonshak, 1994). Various systems, therefore, are tested for their applicability to enhance the effectiveness and economic feasibility (Martinez et al., 2000). Anabaena variabilis, Lyngbya majuscule, Nostoc muscorum and Oscillatoria salinas are established 
cyanobacterial treatment systems, especially for textile industry effluents (Kumar et al., 2016).

Cyanobacteria perform photosynthesis in distinctive folds instead of chloroplasts, as they lack internal membrane-bound organelles like green plants. Several functional groups (carboxyl, phosphonate, amine and hydroxyl groups) are present on the bacterial cell wall that helps with metal binding and biosorption (Doyle et al., 1980). Certain cyanobacterial strains produce Extracellular Polymeric Substances (EPS), which potentially absorb heavy metals from their surroundings (Kulkarni et al., 2010). Biosorption on lignocellulosic wastes and by-products was identified as an alternative to the existing waste management technologies applied for toxic metal ions and dyes. Studies have demonstrated the use of bacteria as biosorbents - for example, Streptomyces sp. (Saurav \& Kannabiran, 2011). Since marine environments are characterised by the presence of high salt and ion contents, the use of marine organisms for bioremediation of metals present in sewage is considered (Deng \& Wang, 2012).

Spirulina sp. can be cultivated worldwide, in hot and alkaline environments; the culture ensures hygiene, as no other organisms can survive and contaminate the culture. There is very little information about the use of Spirulina platensis in bioremediation technologies (Soeprobowati \& Hariyati, 2014) but has been considered an excellent candidate for bioremediation due to its tolerance for toxic heavy metals and biosorption capacity (Murali \& Mehar, 2014; Çelekli et al., 2012). It was first used for domestic wastewater treatment in 1974 (Dolatabadi \& Hosseini, 2016). The bioremediation potential of Spirulina sp. has also been utilised to exclude heavy metals and limit the saturation of nitrate and phosphorus in water bodies (Fariduddin et al., 2017).

Additionally, this cyanobacterium is also used for bioremediation of water polluted with petroleum hydrocarbons (Ciferri, 1983), pesticides (Khan et al., 2005), estrogens (Shi et al., 2010), radioactive elements (Fukuda et al., 2014) and fluoride ions (Tabagari et al., 2019). Spirulina sp. was used for biosorption of $\mathrm{Cr}^{3+}, \mathrm{Cd}^{2+}$ and $\mathrm{Cu}^{2+}$ ions (Chojnacka et al., 2005).

Culturing S. platensis in low metal concentrations can be potentially used for tertiary treatment of metal-contaminated effluent (Dolatabadi \& Hosseini, 2016). Several researchers have also attempted to find suitable desorbing solutions to recover metals from the biomass after cultivating it on wastewater; such reuse of the biological sorbent is better at addressing both environmental and economic issues (Mehta et al., 2002). Miazek et al. (2015) suggested the use of metalcontaining wastewater as replenishment for microalgae growth in nutrient-deficient media.
Spirulina sp., though has a meagre capacity to bind to metal ions and a low tolerance for heavy metals, has considerable potential to precipitate them (Fariduddin et al., 2017). Using Spirulina sp. as a precipitation agent has gained attention recently; the passive metal ion adsorption rate was observed to be accelerated in S. platensis (Doshi et al., 2007). A study by König-Péter et al. (2015), studied the biosorption efficiency of S. platensis-S. maxima cells in a system containing $1.0 \mathrm{~g} / \mathrm{l}$; it was found that about $80 \%$ of the heavy metal ions could be removed, in the optimal $\mathrm{pH}$ range of 4-6. The specific adsorption of both $\mathrm{Pb}^{2+}$ and $\mathrm{Zn}^{2+}$ increased at low concentration and decreased when dead S. platensis biomass concentration exceeded $0.1 \mathrm{~g} / \mathrm{l}$ (Palaniswamy \& Veluchamy, 2017). A study by Al-Homaidan et al. (2015) showed greater than $91 \%$ of $\mathrm{Pb}^{2+}$ removal at a concentration of $2 \mathrm{~g}$ of S. platensis in $100 \mathrm{mg} / \mathrm{l}$ of lead initial concentration $\left(\mathrm{pH} 3 ; 26^{\circ} \mathrm{C}\right) . S$. platensis has great potential as an eco-friendly bio-adsorbent for the removal of Copper from aqueous solutions (Çelekli et al., 2012). S. platensis has shown to be effective in bioremediating dyes; the potential was enhanced using micro or nanoparticles (Dotto et al., 2019). Thereby, it can assist in designing and developing low-cost approaches for the large-scale synthesis of nanoparticles and bioremediation approaches (Priyadarshini et al., 2019).

Nitrate and phosphorus contamination is another major problem of freshwater sources. Due to its mixotrophic nature, $S$. platensis has the potential to reduce biological oxygen demand (BOD) of high carbon-containing wastewater (Kulkarni et al., 2010). Application of Spirulina sp. to minimise and eliminate nitrate and phosphate from the wastewater is established (Fariduddin et al., 2017).

Most of the research conducted for the exclusion of heavy metal from wastewater used dead biomass. The use of dead biomass is favourable - it can tolerate high concentrations of toxic heavy metal ions, nutrient supply is not unnecessary and culture conditions are not limiting (Mehta et al., 2002; KőnigPéter et al., 2014); thus, a potentially cost-effective way of removing toxins from industrial wastewaters (Rangsayatorn et al., 2004). Studies about processes for heavy metal uptake by dead biomass Spirulina are available (Rangsayatorn et al., 2004), but sparsely for the use of its live biomass. Doshi et al. (2007) first proposed live Spirulina sp. as a stronger candidate than dry biomass for the management of industrial wastewater. Future work is necessary as many uncertainties are associated with the development of wastewater treatment by live biomass of Spirulina sp. (Chen \& Pan, 2002).

Chen \& Pan (2004) concluded that living Spirulina cells had a high tolerance to lead (concentration below $50 \mathrm{mg} / \mathrm{L}$ ) and are good adsorbing agents. The growth response of Spirulina to 
toxic heavy metals depends on the metal involved as in its mechanism of tolerance (Thomson \& Kurup, 2010). According to Thomson \& Kurup (2010), Zinc (up to $10 \mu \mathrm{g} / \mathrm{ml}$ ) and Iron (up to $100 \mu \mathrm{g} / \mathrm{ml}$ ) showed a growth-promoting effect in $S$. platensis and established the order of toxicity, $\mathrm{Hg}>\mathrm{Ni}>\mathrm{Cu}>\mathrm{Zn}>\mathrm{Fe}$ (Thomson \& Kurup, 2010). Murthy et al. (1989) demonstrated that Mercury ions at low concentrations affect the transfer of energy within phycobilisomes and at high concentrations showed 50\% inhibition of Hill activity in S. platensis (Murthy et al., 1989). In another experiment, heavy metal-treated $S$. platensis showed capability for the accumulation of tenfold more $\mathrm{Cu}$ and $\mathrm{Zn}$ than control cells (Nalimova et al., 2005).

No concrete evidence for the mechanisms of heavy metal toxicity in S. platensis has been reported (Nalimova et al., 2005), but it can be related to the precipitation of heavy metals, reduction to unavailable compounds or production of complexes with secreted metabolites Tomsett \& Thurman (1988).

\section{Use of Sewage as the Medium for S. platensis and its}

\section{Applications}

In India, National Environmental Engineering Research Institute (NEERI), Nagpur has developed an algae cultivation technique in sewage oxidation pond systems. While, mass production of Single Cell Protein (SCP) from cyanobacteria on sewage is established by National Botanical Research Institute (NBRI), Lucknow and Central Food Technological Research Institute (CFTRI), Mysore. The SCP is produced and is further utilised as animal feed (Kulkarni et al., 2010). Algae on sewage serve a dual purpose of cleaning up potential environmental pollution and producing valuable protein. Similarly, an effective and cost-efficient technique needs to be established for cyanobacteria.

Wastewater is used as a source of nutrients; S. platensis is found to grow better in diluted sewage when improved with sodium carbonate or sodium bicarbonate and nutrients in different proportions. This further screened, is added to aquaculture to feed fish or dried in a small solar drier for animal feed (Kulkarni et al., 2010). Soeprobowati \& Hariyati (2014) suggested the use of S. platensis as a metal absorbent and further as fertiliser, after bioremedial processes. Lead, Mercury, Cadmium and Arsenic are common in agricultural areas and also frequently adulterate Spirulina cultures (Al-Dhabi, 2013).

Michalak et al. (2019) studied the potential of S. platensis as a biosorbent for nutrients. They further also proposed its application as a valuable carrier of metal ions for the production of bioactive additives for the improvement of insulin resistance in horses. The commercially grown and consumed Spirulina supplements have traces of inorganic elements and heavy metals, in the concentration that do not exceed the present regulation levels. If appropriate measures are taken, they can be considered safe food (Al-Dhabi, 2013). This application is the potential to combat the issues of contaminated biomass.

Some changes in the Spirulina sp. occur after being used to bioremediate sewage. Studies report a decrease in the biomass of Spirulina platensis, pigment (phycocyanin) concentration and changes in their chemical pathways when grown on metalrich medium or sewage (Doke et al., 2015). The rising concentration of heavy metals undeviatingly affects the phycocyanin generation in Spirulina sp. (Doke et al., 2015). Cu and $\mathrm{Zn}$ were reported to directly affect the photosynthetic pathways, resulting in a decline in cell growth (Nalimova et al., 2005). In vivo, Mercury results in the breakdown of both light and dark photosynthetic reactions, by substituting the central atom of chlorophyll, magnesium (Patra \& Sharma, 2000).

Changes and variations in the biomass yield and chemical composition of Spirulina should be considered for extracting bioactive compounds or in its application as a food supplement or fertiliser. Spirulina platensis is a potential organism for a cost-effective and environment-friendly wastewater treatment technique.

\section{Conclusion}

Overpopulation and heavy industrialization in the 2000s have increased the generation of wastes and sewage, which when treated is let out in the water bodies. Physicochemical methods of sewage treatment are mostly environmentally degrading and require heavy machinery, increasing the cost of the process. Consequently, the centre of attention has shifted to bioremediation. Microorganisms utilise the organic and inorganic nutrients from the sewage, thereby reducing the pollutant load. Photosynthetic cyanobacteria, such as Spirulina platensis, can thrive and reproduce in lower bioavailability. Because of their simple growth requirements such as sunlight, carbon dioxide; easiness in their genome manipulations and well-documented applications, there is a need and a good chance for optimal utilisation of cyanobacteria. Hence, Spirulina platensis is an organism of choice for bioremediation.

With several bioactive compounds and catalytic enzymes, this cyanobacteria has proven to degrade heavy metals as well as biological contaminants. Moreover, the biomass generated during sewage treatment can be utilised to extract commercially valued products (bioactive compounds) or nutrient-enriched food supplements for humans and animals. 
Even though S. platensis has many advantages, it needs to be explored for using its potential at maximum levels. Its industrial application for mass production of the desired compound is technologically challenging and will need high-efficiency photosynthetic bioreactors with minimum operating costs. There is a need to develop cultivation systems that harness the photosynthetic capability of $S$. platensis for discovering green paths to produce industrial products. That being said, $S$. platensis is a potential, dual solution for combating issues of wastewater treatment and mass-production for further application.

\section{Acknowledgements}

We acknowledge the financial support received from University of Mumbai as Minor Research Project.

\section{Compliance With Ethical Standards}

\section{Authors' Contributions:}

Author AP1 and AA designed the study, AP1, AP2 and PP wrote the first draft of the manuscript, AP2 corrected and formatted the manuscript, AA reviewed and finalised the manuscript. All authors read and approved the final manuscript.

\section{Conflict of Interest}

The authors declare that there is no conflict of interest.

\section{Ethical Approval}

For this type of study, formal consent is not required.

\section{References}

Abou-Shanab, R. A., Hwang, J., Cho, Y., Min, B., \& Jeon, B. (2011). Characterization of microalgal species isolated from freshwater bodies as a potential source for biodiesel production. Applied Energy, 88(10), 33003306. https://doi.org/10.1016/j.apenergy.2011.01.060

Al-Dhabi, N. A. (2013). Heavy metal analysis in commercial Spirulina products for human consumption. Saudi Journal of Biological Sciences, 2(4), 383-388. https://doi.org/10.1016/j.sjbs.2013.04.006

Al-Homaidan, A. A., Al-Abbad, A. F., Al-Hazzani, A. A., AlGhanayem, A. A., \& Alabdullatif, J. A. (2015). Lead removal by Spirulina platensis biomass. International Journal of Phytoremediation, 18(2), 184-189. https://doi.org/10.1080/15226514.2015.1073673

Amin, M., Alazba, A., \& Manzoor, U. (2014). A review of removal of pollutants from water/wastewater using different types of nanomaterials. Advances in Materials
Science and Engineering, 2014, 1-24, https://doi.org/10.1155/2014/825910

Anwer, R., Khursheed, S., \& Fatma, R. (2012). Detection of Immunoactive Insulin in Spirulina. Journal of Applied Phycology, 24, 583-591. https://doi.org/10.1007/s10811011-9757-1

Barrón, B. L., Torres-Valencia, J. M., Chamorro-Cevallos, G., \& Zúñiga-Estrada, A. (2007). Spirulina as an antiviral agent. In M. E. Gershwin \& A. Belay (Eds.), Spirulina in Human Nutrition and Health (1st ed., pp. 227-240). CRC Press.

Beauvais-Flück, R., Slaveykova, V., \& Cosio, C. (2018). Molecular effects of inorganic and methyl mercury in aquatic primary producers: Comparing impact to a macrophyte and a green microalga in controlled conditions. Geosciences, $8(11)$, 393. https://doi.org/10.3390/geosciences8110393

Boone, D. R., \& Castenholz, R. W. (2001). Volume One : The Archaea and the deeply branching and phototrophic bacteria. In G. M. Garrity (Ed.), Bergey's manual of Systematic Bacteriology (Vol. 1, p. 722). Springer-Verlag. Boopathy, R. (2000). Factors limiting bioremediation technologies. Bioresource Technology, 74(1), 63-67. https://doi.org/10.1016/s0960-8524(99)00144-3

Buchweitz, M. (2016). Natural solutions for blue colors in food. In R. Carle, \& R. Schweiggert (Eds.), Handbook on Natural Pigments in Food and Beverages (pp. 355-384). Woodhead Publishing. https://doi.org/10.1016/ b978-0-08-100371-8.00017-8

Capelli, B., \& Cysewski, G. (2010). Potential health benefits of Spirulina microalgae. Nutrafoods, 9(2), 19-26. https://doi.org/10.1007/bf03223332

Çelekli, A., Yavuzatmaca, M., \& Bozkurt, H. (2012). An ecofriendly process: predictive modelling of copper adsorption from aqueous solution on Spirulina platensis. Journal of Hazardous Materials, 173(1-3), 123129. https://doi.org/10.1016/j.jhazmat.2009.08.057

Cepoia, L., \& Zinicovscaia, I. (2002). Spirulina platensis as a model object for the environment bioremediation studies. In O. Konur (Ed.), Handbook of Algal Science, Technology and Medicine (pp. 629-640). Academic Press.

Chamorro, G., \& Salazar, M. (1990). Estudio teratogénico de Spirulina en ratón [Teratogenic study of Spirulina in mice]. Archivos Latinoamericanos de Nutrición, 40(1), 86-94.

Chen, H., \& Pan, S. (2002). Bioremediation potential of Spirulina: Toxicity and biosorption studies of lead. 
Journal of Zhejiang University Science B, 6B(3), 171-174. https://doi.org/10.1631/jzus.2005.b0171

Chojnacka, K., Chojnacki, A., \& Górecka, H. (2005). Biosorption of $\mathrm{Cr}^{3+}, \mathrm{Cd}^{2+}$ and $\mathrm{Cu}^{2+}$ ions by blue-green algae Spirulina sp.: kinetics, equilibrium and the mechanism of the process. Chemosphere, 59(1), 75-84. https://doi.org/10.1016/j.chemosphere.2004.10.005

Ciferri, O. (1983). Spirulina, the edible microorganism. Microbiological Reviews, 47(4), 551-578.

Deng, X., \& Wang, P. (2012). Isolation of marine bacteria highly resistant to mercury and their bioaccumulation process. Bioresource Technology, 121, 342-347. https://doi.org/10.1016/j.biortech.2012.07.017

Doke, J., Kalyanraman, V., \& Ghole, V. (2015). Bioremediation potential of Spirulina sp.: Toxicity and sorption studies of $\mathrm{Co}$ and $\mathrm{Pb}$. International Journal on Algae, 7(2), 118128. https://doi.org/10.1615/InterJAlgae.v7.i2.30

Dolatabadi, S., \& Hosseini, S. (2016). Wastewater treatment using Spirulina platensis. Journal of Chemical, Biological and Physical Sciences, 6(4), 1239-1246.

Doshi, H., Ray, A., \& Kothari, I. L. (2007). Bioremediation potential of live and dead S. platensis: Spectroscopic, kinetics and SEM studies. Biotechnology and Bioengineering, 96(6), 1051-1063. https://doi.org/10.1002/bit.21190

Dotto, G., Cadaval, T., \& Pinto, L. (2012). Use of Spirulina platensis micro and nanoparticles for the removal of synthetic dyes from aqueous solutions by biosorption. Process Biochemistry, 47(9), 1335-1343. https://doi.org/10.1016/j.procbio.2012.04.029

Doyle, R. J., Matthews, T. H., \& Streips, U. N. (1980). Chemical basis for selectivity of metal ions by the Bacillus subtilis cell wall. Journal of Bacteriology, 143(1), 471-480. https://doi.org/10.1128/JB.143.1.471-480.1980

Elleuch, B., Bouhamed, F., Elloussaief, M., \& Jaghbir, M. (2018). Environmental sustainability and pollution prevention. Environmental Science and Pollution Research, 25(19), 18223-18225. https://doi.org/10.1007/s11356-0170619-5

Eriksen, N. T. (2008). Production of phycocyanin-a pigment with applications in biology, biotechnology, foods and medicine. Applied Microbiology and Biotechnology, 80(1), 1-14. https://doi.org/10.1007/s00253-008-1542-y

Falquet, J. (2008). The nutritional aspects of Spirulina. Antennae Technologies. Switzerland.

Fariduddin, Q., Varshney, P., \& Ali, A. (2017). The perspective of nitrate assimilation and bioremediation in Spirulina platensis (a non-nitrogen fixing cyanobacterium): An overview. Journal of Environmental Biology, 39(5), 547557. https://doi.org/10.22438/jeb/39/5/MS-172

Fukuda, S., Lwamoto, K., Asumi, M., Yokoyama, A., Nakayama, T., Ishida, K., Inouye, I., \& Shraiwa, I. (2014). Global searches for microalgae and aquatic plants that can eliminate radioactive caesium, iodine and strontium from the radio-polluted aquatic environment. Journal of Plant Research, 127, 79-89. https://doi.org/10.1007/s10265-013-0596-9

Geitler, L. (1925). Cyanophyceae. In A. Pascher (Ed.), Die Süsswasser-Flora Deutschlands, Österreichs und der Schweiz, 12 (pp. 1-450). Jena: Gustav Fischer.

Gomont, M. (1892). Monographie des Oscillariées (Nostocacées Homocystées) [Oscillariate Monograph (Homocysted Nostocaceae)]. Annales des Sciences Naturelles Botanique, 7(16), 91-264.

Gouma, S., Fragoeiro, S., Bastos, A., \& Magan, N. (2014). Bacterial and fungal bioremediation strategies. In S. Das (Ed.), Microbial biodegradation and bioremediation (pp. 301-323). Elsevier. https://doi.org/10.1016/b978-0-12800021-2.00013-3

Gupta, S., Mohan, K., Prasad, R., Gupta, S., \& Kansal, A. (1998). Solid waste management in India: options and opportunities. Resources, Conservation \& Recycling, 24(2), 137-154 $\quad$ https://doi.org/10.1016/s09213449(98)00033-0

Habib, M., Parvin, M., Huntington, T., \& Hasan, M. (2008). A review on culture, production and use of spirulina as food for humans and feed for domestic animals and fish. FAO Fish. Aquaculture Circular No. 1034. FAO, Rome.

Hayashi, K., Hayashi, T., \& Kojima, J. (1996). A natural sulfated polysaccharide, calcium spirulan, isolated from Spirulina platensis: In vitro and ex vivo evaluation of anti-herpes simplex virus and anti-human immunodeficiency virus activities. AIDS Research and Human Retroviruses, 12(15), 1463-1471. https://doi.org/10.1089/aid.1996.12.1463

Hosseini, S. M., Khosravi-Darani, K., \& Mozafari, M. R. (2013) Nutritional and medical applications of Spirulina microalgae. Mini-Reviews in Medicinal Chemistry, 13(8),

1231-1237. https://doi.org/10.2174/1389557511313080009

Juwarkar, A., Singh, S., \& Mudhoo, A. (2001). A comprehensive overview of elements in bioremediation. Reviews in Environmental Science and Bio/Technology, 9(3), 215288. https://doi.org/10.1007/s11157-010-9215-6

Khan, Z., Bhadouria, P., \& Bisen, P. (2005) Nutritional and therapeutic potential of Spirulina. Current 
Pharmaceutical Biotechnology, 6(5), 373-379. https://doi.org/10.2174/138920105774370607

Komárek, J., \& Lund, J. W. G. (1998). What is Spirulina platensis in fact? Algological Studies, 58, 1-13.

Kőnig-Péter, A., Csudai, C., Felinger, A., Kilár, F., \& Pernyeszi, T. (2014). Potential of various biosorbents for $\mathrm{Zn}$ (II) removal. Water, Air, \& Soil Pollution, 225(2089), 1-9. https://doi.org/10.1007/s11270-014-2089-4

Koristka, C. (1891) Archiv für die naturwissenschaftliche Landesdurchforschung von Bohmen [Archive for the scientific research of the country of Bohemia]. Forgotten Books.

Kulkarni, S. D., Auti, T., \& Saraf, S. (2010). Bioremediation study of dairy effluent by using Spirulina platensis. Research Journal of Life Sciences, Bioinformatics, Pharmaceutical and Chemical Sciences, 1(6), 317-325. https://doi.org/10.26479/2016.0106.04

Kumar, B. N. P., Mahaboobi, S., \& Satyam, S. (2016). Cyanobacteria: A potential natural source for drug discovery and bioremediation. Journal of Industrial Pollution Control, 32(2), 508-517. https://doi.org/10.3389/fmicb.2016.00529

Mackay, D., \& Frasar, A. (2000). Bioaccumulation of persistent organic chemicals: mechanisms and models. Environmental Pollution, 110(3), 375-391. https://doi.org/10.1016/S0269-7491(00)00162-7

Martinez, M. E., Sanchez, S., Jimenez, J. M., Yousf, F. E., \& Munoz, L. (2000). Nitrogen and phosphorus removal from urban wastewater by the microalga Scendesmus obliquus. Bioresource Technology, 73(3), 263-272. https://doi.org/10.1016/S0960-8524(99)00121-2

Mary Leema, J. T., Kirubagaran, R., Vinithkumar, N. V., Dheenan, P. S., \& Karthikayulu, S. (2010). High value pigment production from Arthrospira (Spirulina) platensis cultured in seawater. Bioresource Technology, 101(23), 9221-9227. https://doi.org/10.1016/j.biortech.2010.06.120

Masojídek, J., \& Torzillo, G. (2008). Mass cultivation of freshwater microalgae. Encyclopedia of Ecology, 2008, 2226-2235. https://doi.org/10.1016/b978-0080454054.00830-2

Mehta, S., Tripathi, B., \& Gaur, J. (2002). Enhanced sorption of $\mathrm{Cu}^{2+}$ and $\mathrm{Ni}^{2+}$ by acid-pretreated Chlorella vulgaris from single and binary metal solutions. Journal of Applied Phycology, 14, 267-273. https://doi.org/10.1023/a:1021149119472

Miazek, K., Iwanek, W., Remacle, C., Richel, A., \& Goffin, D. (2015). Effect of metals, metalloids and metallic nanoparticles on microalgae growth and industrial product biosynthesis: A review. International Journal of Molecular Sciences, 16(10), 23929-23969. https://doi.org/10.3390/ijms161023929

Michalak, I., Mironiuk, M., Godlewska, K., Trynda, J., \& Marycz, K. (2019). Arthrospira (Spirulina) platensis: An effective biosorbent for nutrients. Process Biochemistry, 88, 129-137. https://doi.org/10.1016/j.procbio.2019.10.004

Murali, O. M., \& Mehar, S. K. (2014). Bioremediation of heavy metals using Spirulina. International Journal of Geology, Earth \& Environmental Sciences, 4(1), 244-249.

Murthy, S. D. S., Sabat, S. C., \& Mohanty, P. (1989). Mercuryinduced inhibition of photosystem ii activity and changes in the emission of fluorescence from phycobilisomes in intact cells of the Cyanobacterium, Spirulina platensis. Plant Cell Physiology, 30(8), 11531157. https://doi.org/10.1093/oxfordjournals.pcp.a077858

Nalimova, A. A., Popova, V. V., Tsoglin, L. N., \& Pronina, N. A. (2005). The effects of copper and zinc on Spirulina platensis growth and heavy metal accumulation in its cells. Russian Journal of Plant Physiology, 52(2), 229-234. https://doi.org/10.1007/s11183-005-0035-4

Palaniswamy, R., \& Veluchamy, A. (2017). Biosorption of heavy metals by Spirulina platensis from electroplating industrial effluent. Environmental Science: An Indian Journal, 13(4), 139.

Paramanya, A., Jha, P., \& Ali, A. (2019). Bioactive compounds in Spirulina sp.: Applications and potential health effects. In J. K. Sundaray, \& M. A. Rather (Eds.), Next generation research in aquaculture (pp.197-218). BioGreen Books.

Patra, M., \& Sharma, A. (2000). Mercury toxicity in plants. Botanical Review, 66, 379-422. https://doi.org/10.1007/BF02868923

Pierzynski, G. M., Sims, J. T., \& Vance, G. F. (1994). Soil and environmental quality. Lewis Publisher.

Priyadarshani, I., Sahu, D., \& Rath, B. (2011). Microalgal bioremediation: Current practices and perspectives. Journal of Biochemical Technology, 3(3), 299-304.

Priyadarshini, E., Priyadarshini, S. S., \& Pradhan, N. (2019). Heavy metal resistance in algae and its application for metal nanoparticle synthesis. Applied Microbiology and Biotechnology, 103, 3297-3316. https://doi.org/10.1007/s00253-019-09685-3

Rangsayatorn, N., Pokethitiyook, P., \& Upatham, E. (2004). Cadmium biosorption by cells of $S$. platensis TISTR 8217 immobilized in alginate and silica gel. Environment 
International,

$30(1)$

57-63.

https://doi.org/10.1016/S0160-4120(03)00146-6

Rehman, A., Ali, A., Muneer, B., \& Shakoori, A. R. (2007).

Resistance and biosorption of mercury by bacteria isolated from industrial effluents. Pakistan Journal of Zoology, 39(3), 137-146.

Richmond, A. E. (1986). Microalgae. Critical Reviews in Biotechnology,

$4(4)$,

349-438.

https://doi.org/10.3109/07388558609150801

Samantaray, D., Mohapatra, S., \& Mishra, B. B. (2014). Microbial bioremediation of industrial effluents. In S. Das (Eds.), Microbial biodegradation and bioremediation (pp. 325-339). Elsevier. https://doi.org/10.1016/b978-0-12-800021-2.00014-5

Sánchez, M., Bernal-Castillo, J., Rozo, C., \& Rodríguez, I. (2003). Spirulina (Arthrospira): An edible microorganism. A review. Universitas Scientiarum, 8, 724.

Saurav, K., \& Kannabiran, K. (2011). Biosorption of Cr(III) and $\mathrm{Cr}(\mathrm{VI})$ by Streptomyces VITSVK9 spp. Annals of Microbiology, 61(4), 833-841. https://doi.org/10.1007/s13213-011-0204-y

Shi, W., Wang, L., Rousseau, D., \& Lens, P. (2010). Removal of estrone, $17 \alpha$-ethinylestradiol, and $17 \beta$-estradiol in algae and duckweed-based wastewater treatment systems. Environmental Science and Pollution Research, 17, 824833. https://doi.org/10.1007/s11356-010-0301-7

Soeprobowati, T. R., \& Hariyati, R. (2014). Phycoremediation of $\mathrm{Pb}^{+2}, \mathrm{Cd}^{+2}, \mathrm{Cu}^{+2}$, and $\mathrm{Cr}^{+3}$ by Spirulina platensis (Gomont) Geitler. American Journal of BioScience, 2(4), 165-170. https://doi.org/10.11648/j.ajbio.20140204.18

Sperling, M. (2007). Basic principles of wastewater treatment. IWA Publishing.

Tabagari, I., Kurashvili, M., Varazi, T., Adamia, G., Gigolashvili, G., Pruidze, M., Chokheli, L., Khatisashvili, G., \& Niemsdorf, P. (2019). Application of Arthrospira (Spirulina) platensis against chemical pollution of water. Water, 11(9), 1759. https://doi.org/10.3390/w11091759

Tanticharoen, M., Reungjitchachawali, M., Boonag, B., Vonktaveesuk, P., Vonshak, A., \& Cohen, Z. (2009). Optimization of gamma-linolenic acid (GLA) production in Spirulina platensis. Journal of Applied Phycology, 6 , 295-300. https://doi.org/10.1007/BF02181942

Tchounwou, P., Yedjou, C., Patlolla, A., \& Sutton, D. (2012). Heavy metal toxicity and the environment. In A. Luch (Ed.), Molecular, clinical and environmental toxicology (pp. 133-164). Experientia Supplementum, 101. Springer. https://doi.org/10.1007/978-3-7643-8340-4 6

Thomson, A. M., \& Kurup, G. (2010). Heavy metal tolerance and metal induced oxidative stress in Spirulina platensis. Asian Journal of Microbiology, Biotechnology \& Environmental Sciences, 12(2), 461-468.

Tomsett, A. B., \& Thurman, D. A. (1988). Molecular biology of metal tolerances of plants. Plant, Cell \& Environment, 11(5), 383-394. $\quad$ https://doi.org/10.1111/j.13653040.1988.tb01362.x

Torzilla, G., \& Vonshak, A. (1994). Effect of light and temperature on photosynthetic activity of the cyanobacterium S. platensis. Biomass \& Bioenergy, 6(5), 399-408. https://doi.org/10.1016/0961-9534(94)00076-6

United Nations Environment Programme. (2002). First National Communication of Kenya to the Conference of the Parties to the United Nations Framework Convention on Climate Change (pp. 172). Retrieved on January 30, 2021, from http://wedocs.unep.org/

Vo, T., Ngo, D., \& Kim, S. (2008). Nutritional and pharmaceutical properties of microalgal Spirulina. In S. Kim (Ed.), Handbook of marine microalgae (pp. 299308). Academic Press. https://doi.org/10.1016/b978-012-800776-1.00019-4

Vonshak, A., Chanawongse, L., Bunnag, B., \& Tanticharoen, M. (1996). Light acclimation and photoinhibition in three Spirulina platensis (Cyanobacteria) isolates. Journal of Applied Phycology, 8, 35-40.

Wan, D., Wu, Q., \& Kuča, K. (2016). Spirulina. In R. C. Gupta (Ed.), Nutraceuticals: Efficacy, safety and toxicity (pp. 569-583). Academic Press. https://doi.org/10.1016/C2014-0-01870-9

Wang, J., \& Chen, C. (2009). Biosorbents for heavy metals removal and their future. Biotechnology Advances, 27(2), 195-226. https://doi.org/10.1016/j.biotechadv.2008.11.002

Wexler, P. (2004). Encyclopedia of toxicology. 3rd ed. Academic Press.

Whitton, B. (1992). Diversity, ecology and taxonomy of the Cyanobacteria. In N. Mann, \& N. Carr (Eds.), Photosynthetic Prokaryotes (pp. 1-37). Biotechnology Handbooks, vol 6. Springer.

World Commission on Environment and Development. (1987). Our common future. Oxford University Press. 